\title{
OBITUARY
}

\section{PROFESSOR NORMAN SIMMONDS}

\section{December 1922 to 4 January 2002}

Norman Simmonds was an outstanding member of the group of British Tropical Agriculturalists who served overseas with great distinction during and immediately after the Second World War. He was then equally successful and influential in British academia and as an internationally respected researcher. He will be remembered as a plant breeder, a geneticist, a teacher and author, and as incisive commentator on current affairs in tropical agriculture. Simmonds had a long association with Experimental Agriculture, serving on its Editorial Board from 1978 to 1998, and as a Book Review Editor from 1978 to 1987.

Simmonds was born in Bedford, England. His father was a civil servant, his mother was of Scottish farming origin. Farming, or at least crops and their improvement, and Scotland were the passions of his life. He was educated at Whitgift School in Croydon and Downing College, Cambridge, taking a first class degree in the Natural Sciences Tripos Part II (Botany) with an emphasis on plant breeding and genetics. He won a Colonial Agricultural Scholarship, which took him to the Imperial College of Tropical Agriculture in Trinidad in 1945.

Simmonds stayed with the College until 1959. He was appointed as a lecturer in botany and specialized in bananas. He explained the cytogenetics of bananas: almost all edible bananas are derived from Musa acuminata (A genome) and M. balbisiana (B genome). He travelled to Africa and the Far East collecting material. His breeding strategy, derived from an understanding of the evolution of the crop, was based on ploidy, different genomes and a broad genetic base. This approach became the theme of his career. The work led to two books, Bananas (1959, revised by Stover and Simmonds, 1987) and The Evolution of Bananas (1962), by which Simmonds became widely known. To this day, Simmonds' plant collection is used in plant breeding. While with the College, Simmonds also involved himself with sugar cane, another clonally propagated crop with a complex genome, and interested himself in the full range of tropical crops.

In 1959, Simmonds joined the John Innes Institute, then at Hertford, England as head of potato genetics. His interest in potatoes continued when he joined the Scottish Plant Breeding Station (SPBS) as Director in 1965. He had realized that North West European potatoes, collectively termed Tuberosum, were derived from only a few effectively random ancient introductions from the great many tetraploid cultivars grown in the high Andes, and collectively termed Andigena. While a few 'primitive' cultivars and also some wild species had been used as sources of resistance genes, by the time commercially acceptable cultivars were bred from them, by repeated back-crossing to I, little derived from them remained apart from the genes. 
The reason for the lack of progress in potato breeding was that the genepool was too small. In 1962, Simmonds visited Peru and Bolivia with Kenneth Dodds, seeking 'weed species' of Solanum in and around cultivated fields. Simmonds' idea was to select material derived from Andigena for adaptation to United Kingdom day lengths and other requirements, repeating the process by which farmers had developed Tuberosum, before crossing with I. He hoped to select acceptable cultivars from initial crosses, having already demonstrated hybrid vigour in Andigena $\times$ Tuberosum crosses. As the Andigena material improved, it was renamed Neo-Tuberosum.

Simmonds left SPBS after ten years and, in 1975, joined the East of Scotland College of Agriculture (ESCA). The administration of SPBS was not to his taste during the implementation of the Rothchild-inspired changes to funding for the UK agricultural research system. The SPBS' loss was certainly the ESCA's gain. He welcomed the return to academia, and was invigorated thereby.

As his circle of professional contacts throughout the world widened Simmonds' encyclopaedic knowledge of crops and their origins broadened ever further. He realized that specialists would benefit from understanding other crops, as he had himself. This prompted another book (with more than 80 contributing authors!), The Evolution of Crop Plants (1976, updated by Smartt and Simmonds in 1955), which captured many of his ideas of genetic-base broadening in crop improvement, and was to prove highly influential. In time, this led to Simmonds playing a key role in the International Plant Genetic Resources Institute's (IPGRI) activities on in vitro conservation. At a conference in 1980, he identified the areas in need of this method of conversation and put them in the context of practical utilization of genetic resources. The conference recommendations guided IPGRI's in vitro activity for the next two decades. Simmonds remained an internationally admired authority on the history of plant genetic resources.

At ESCA, he contributed directly to both undergraduate and postgraduate teaching of the principles of genetics and crop improvement. He published Principles of Crop Improvement (1979, revised by Simmonds and Smartt, 1999) based on his experience and highly practical understanding of statistics. Few who read this book will realize that his statistics were largely self-taught.

At the John Innes Institute, Simmonds took his knowledge of clonally propagated tropical perennial crops to new areas. He became advisor to the West Indies Sugar Cane Breeding Programme and to the Rubber Research Institute of Malaysia (RRIM). The RRIM connection made Simmonds widely known among perennial crop breeders in Malaysia and his influence spread into oil palm in particular. Later he became involved in cacao, his analysis showing that the development of better clones is central to improving yield in the crop. Simmonds' natural authority, his belief that breeding in particular and research in general are economic and essentially cerebral (as opposed to physical) activities coupled with his ability to answer questions in the enquirer's language made him highly effective as an advisor in the commercial sector.

Simmonds 'retired' in 1982. He continued to be heavily and enthusiastically involved with the affairs of the College, primarily as Editor of ESCA News. His retirement was as active as his earlier career. During this period he undertook major consultancies for The World Bank and the Consultative Group for International 
Agricultural Research as well as revising some of his earlier books. He continued to publish original papers in quality, peer-reviewed journals.

His contribution to advances in science was considerable, with the production of eight books and monographs as well as over 215 scientific papers.

Simmonds' clarity of thought, penetrating analyses and independence of spirit made him appear a strong character. At times he seemed to delight in controversy, perhaps sometimes from mischief but never from malice. His observations on current affairs in the Tropical Agriculture Association (UK) Newsletter were pertinent and often amusing, even if they did not always endear him to its entire readership. His students thought very highly of him, as did all those with whom he came into professional contact. Many learned that weak argument would bring a memorable response.

Privately, Simmonds was generous and patient. It is no surprise that fishing was his main hobby, both in the sea but, more especially, on wild Scottish lochs for trout. Typically, his biologically instincts were to the fore with fishing. He identified a crayfish that was thought not to be known in Scotland, published a paper on it and then tied flies to mimic it in the water. We are not told whether they were successful. He published a book on the History of Fly Fishing in Scotland. Other interests included the piano, archery and painting with more than normal skill.

Simmonds married Christa, his secretary at the John Innes Institute. They were a devoted couple but Christa died before Norman, in December 2000: there were no children.

Tropical Agriculture is the poorer for the loss of Norman Simmonds. He will be remembered with respect and affection by the many people he worked with, and the far greater number he influenced, in many countries around the world. His work benefited not only advances in scientific knowledge and understanding, but also some of the poorer people of the world, and will benefit many more in the future. These were Simmonds' real reward. He was a breath of scientific 'fresh air': the members of the Editorial Board of Experimental Agriculture who served with him over the years are proud that he cared so much about the journal and that he gave time so unselfishly to contribute to our collective aims and ambitions for tropical agriculture.

Rob Lockwood 